\title{
FIRMS` PARTICIPATION IN TAX AMNESTY PROGRAM ENGAGED IN FINANCIAL REPORTING MANIPULATION: AN EMPIRICAL EVIDENCE FROM LISTED COMPANIES IN INDONESIA
}

\author{
Gatot Soepriyanto $^{1}$; Yanto Indra ${ }^{2}$; Olivia The ${ }^{3}$; Arfian Zudana ${ }^{4}$ \\ ${ }^{1,2,3}$ Accounting and Finance Department, Faculty of Economics \& Communication, Bina Nusantara University \\ Jl. K. H. Syahdan No. 9, Palmerah, Jakarta 11480, Indonesia \\ ${ }^{4}$ Victoria University of Wellington \\ Kelburn, Wellington 6012, New Zealand \\ ${ }^{1}$ Gsoepriyanto@binus.edu; ${ }^{2}$ yanto.indra@binus.ac.id; ${ }^{3}$ olivia.the@ binus.ac.id; \\ zudana.zudana@gmail.com
}

\begin{abstract}
The research investigated the relation between firms participated in tax amnesty programs and their tendency to manipulate financial statements. The research explored some unique research settings during Indonesia's tax amnesty period in 2016-2017. To examine the association, the researchers employed Beneish's $M$-Score model to categorize the firm's tendency to manipulate its financial statements. As the test variable, it classified the firm's participation in the tax amnesty program with a dummy variable, 1 if the firm participated, and 0 otherwise. To control the variations in financial statements manipulation, it also included firm size, leverage, and profitability in our empirical model. Based on the sample of 796 firm-year observations in the Indonesian Stock Exchange (IDX) from the 2012-2017 period, it is found some evidence that firms participate in tax amnesty programs do not engage in financial statements manipulation. Further analysis of the corporate tax avoidance measures shows that those firms do not engage in tax avoidance activities either. The results suggest that firms participate in the tax amnesty programs are not necessary 'bad firms', and they just participate as a 'symbolic' gesture to get some indirect benefits of the program.
\end{abstract}

Keywords: tax amnesty, corporate tax aggressiveness, financial reporting manipulation

\section{INTRODUCTION}

Tax is one of the largest sources of revenue for the country with corporate income tax as the largest contributor. To achieve its tax revenue target, the Indonesian government has attempted various efforts such as tax incentives for asset revaluation, improving tax administration, access to bank data, and electronic tax payment and submission. Unfortunately, despite the government's best effort to optimize tax revenue, some challenging issues persist. One of the challenges is the different interests between the government and the corporation. While tax is a source of revenue for government; for business, tax is considered a burden that will reduce the net income. Such a different perspective leads to non-compliance with taxpayers through corporate tax avoidance and aggressiveness.

In Indonesia, the issue of corporate tax avoidance and aggressiveness has been around for many years. Recently, Google, Facebook, and Twitter have been fined by the Indonesia government because of their illegal tax avoidance strategies. Google, for example, is suspected of avoiding tax payment in Indonesia. This is because Google considers its legal entity as a non-permanent business entity in Indonesia, which allows them not paying any taxes in Indonesia. Therefore, in 2016, the Indonesian Government forced Google to pay a tax penalty amounting to 5 trillion rupiah (Setyo, 2016). 
Indeed, the corporate tax avoidance and aggressiveness issues stem from various factors, including the difficulty of the tax authority accessing data and information from the banking sector and the financial sector due to the existence of the law on bank secrecy. Issues surrounding taxation also cause many Indonesian assets (from entrepreneurs or public officials) to be rushed out to other countries that have a lower tax rate or even a tax-free country. The favorite tax haven countries for the Indonesian are the British Virgin Islands, Cook Island, Delaware (Texas), and Singapore, as reported in the Panama Papers (Dalby \& Wilson-Chapman, 2019). These assets are certainly not reported in the Annual Tax Return (SPT). The government, especially the Directorate General of Taxes, must respond to this by making a breakthrough or policy in order to bring back the shifted assets as reported in the Panama Papers (Dalby \& Wilson-Chapman, 2019). These assets, therefore, can be used as additional capital to finance Indonesia's development.

One of the ways is by issuing a tax amnesty policy. Tax amnesty aims to increase state revenues. It also aims to improve taxpayer compliance (Muttaqin, 2013). Mukarromah (2016) has reviewed that the tax amnesty policy is the beginning of tax reform in Indonesia. In general, the definition of tax amnesty is a tax pardon given by the government for individuals or entities indicated to carry out tax avoidance by saving their money abroad or not reported the actual asset in their annual tax return. By reporting the assets and paying fines at low rates, the government increases the willingness of those individuals or entities to bring back their assets to Indonesia, and at the same time, to facilitate the government, in this case, the Directorate General of Taxes to extend the existing taxpayers database.

Therefore, in 2016, the Directorate General of Taxes and the Ministry of Finance has implemented a tax amnesty program. Based on Law 11 of 2016 concerning tax amnesty, it states that for companies or communities that are not reporting the actual assets, the government grants pardon to taxpayers to report assets that have not been reported. Besides that, the government gives benefit such as the elimination of taxes that should be owed, the elimination of tax administration sanctions, and the elimination of taxation criminal sanctions on assets acquired, and previously not reported in the Annual Tax Return (SPT), by paying off all tax arrears owned and fees. In other words, it can be said that tax amnesty is a way for taxpayers who have not to comply with reporting actual assets. From the result of the tax amnesty program, which began from 2016 until 2017, the total taxpayers who participated in this program have reached 965.000 people and 191.000 corporate taxpayers (Mustami \& Caturini, 2017). This indicates that many corporates are actually non-tax compliance taxpayers.

Looking at the results of the tax amnesty period during 2016-2017, the researchers have a unique opportunity to observe and categorize the company's compliance with the tax report. This is because the government provides a window of opportunity for firms or individuals to report their unreported assets in returns of a certain percentage of fine and penalties. As such, it is plausible that it can be categorized companies participated in tax amnesty as taxpayers who engage in aggressive tax avoidance strategies by manipulating the records of their assets. In addition, it is very likely that the firms participated in tax amnesty also engages in financial statement manipulation since they need to conceal the fled assets to avoid government scrutiny.

The relationship between corporate tax aggressiveness and financial reporting aggressiveness has been widely discussed and researched lately. Corporate tax aggressiveness often collides with pressure to increase profits. The decision to conduct corporate tax aggressiveness or the aggressiveness of financial reporting is faced with the problem of trade-offs between the two. There are several previous researches, which show the trade-off between accounting and tax financial reporting interests.

Therefore, it is very important to examine whether the corporate tax aggressiveness and the aggressiveness of financial reporting can be done at the same time. There are still various arguments and conflicting evidence in previous researches. The relationship between corporate tax aggressiveness and financial reporting has been investigated previously by Frank, Lynch, and Rego (2009) in the United States (US). The research is conducted using the companies in Graham and Tucker samples that are 
allegedly involved in tax sheltering cases for the period 1991-2005. Frank, Lynch, and Rego (2009) have found that there is a positive relationship between corporate tax aggressiveness and financial reporting aggressiveness. This indicates that there is no book-tax trade-off which is allegedly caused by the increasing number of tax loopholes that companies can use due to differences in accounting principles and taxation regulations.

Ko, Choi, and Kim (2012) have examined the behavior of companies in South Korea that are conducting aggressive financial reporting and aggressive tax reporting simultaneously. The results show that the aggressiveness of financial reporting is negatively related to the aggressiveness of tax reporting. This is because the companies in South Korea have unique characteristics. Besides that, aggressive financial reporting is difficult to unite with the aggressive reporting of taxes because, in South Korea, the tax rate is lower. In addition, the rules between accounting and taxation show a lot of conformity and the high rules of law adopted.

Lennox, Lisowsky, and Pittmen (2013) have examined the relationship between aggressive tax planning and the frequency of suspected accounting fraud. They have found that tax aggressive companies tend not to commit to accounting fraud. In this case, their result does not support the results of Frank, Lynch, and Rego (2009). Likewise, Onuma (2013) has found a negative reciprocal relationship between corporate tax aggressiveness and financial reporting aggressiveness in Japan. It suggests that both decisions are mutually exclusive, so they cannot be done at the same time. It shows that the decision to do corporate tax aggressiveness will sacrifice the aggressive actions on financial reporting and vice versa.

Similar research is also conducted in Indonesia, where Kamila (2014) have found a positive reciprocal relationship between the two decisions, which means there is no trade-off between corporate tax aggressiveness and the aggressiveness of financial reporting. Companies that have been proven to do corporate tax aggressiveness are also alleged to aggressive financial reporting, and vice versa. Research about tax amnesty programs associated with financial reporting irregularities is conducted by Buckwalter et al. (2014). This research has found that firms headquartered in states offering state tax amnesties that are associated with a significantly higher likelihood of engaging in a financial reporting irregularity during the period of the amnesty. However, financial reporting irregularities during the year of the amnesty are only captured for firms headquartered in states offering repeat, but not initial, tax amnesty programs.

Considering the previous discussion, the investigation on the association between firms participated in tax amnesty, and financial statement manipulation is warranted. This research refers to the research of Frank, Lynch, and Rego (2009); Lennox, Lisowsky, and Pittmen (2013); and Buckwalter et al. (2014). The difference between this research and prior research is the inclusion of tax amnesty participation and Beneish M-score to detect financial statement irregularities. This research will employ populations from companies listed on the Indonesia Stock Exchange from the 2012 to 2017 period.

The tax amnesty program offered by the government has encouraged companies to report assets that previously never been reported. In other words, reporting actual assets that they have. In this case, it can be said that the companies participating in the tax amnesty program tend to manipulate previous annual tax reports. In the spirit to conceal that manipulation, companies may also engage in the aggressive financial reports in order to avoid government scrutiny. The tax amnesty program provided by the government in Indonesia provides a unique setting to conduct further research. In that case, the researchers examine the relation between firms participate in tax amnesty and the manipulation in the financial statement. To get a neutral research setting, the researchers test the issue in the period before companies join the tax amnesty program (i.e., before 2016 and 2017) to see whether participants of tax amnesty are engaged in aggressive financial reporting. This research setting allows investigating the firm's behavior on financial reporting manipulations since participants of the tax amnesty program tend to manipulate their financial report in the period before their tax amnesty participation. As such, this 
research will seek to answer the following research question: "Do firms participate in the tax amnesty program also engage in financial statements manipulations?" Based on prior literature and the preceding discussion, the researchers formulate the hypothesis for the research (stated in the alternative form):

$\mathrm{Ha}=$ Firms that participated in tax amnesty are associated with financial reporting manipulations.

\section{METHODS}

The data used in this research are companies listed on the Indonesia Stock Exchange (IDX) from 2012 to 2017. Companies that have been listed on the Indonesia Stock Exchange are considered as 'go public' company, which the financial statements can be accessed directly, and the researchers can obtain the required valid information. The number of populations in this research is 600 companies. This research considers all firms in IDX based on a certain criterion. The selection criteria for the companies included in the populations are: (1) company must have the necessary data to calculate independent variables and dependent variable, (2) exclusion of banks, multi finance, securities, and insurance companies, (3) company must conduct an IPO at the year 2012 or before, (4) the financial statement must reported in rupiah, (5) companies are never delisted from IDX during research period, (6) companies whose financial statements or all data can be accessed or obtained through the website of the Indonesia Stock Exchange. There are 175 companies remaining based on those mentioned specifications. The sample selection process in this research is depicted in Table 1.

Table 1 Companies Selection and Distribution

\begin{tabular}{cc}
\hline Companies Selection & Firms \\
\hline Total firms from IDX database (2017) & 600 \\
Less: Financial institution firms & $(86)$ \\
Less: Firms that have initial public offering after 2012 & $(142)$ \\
Less: Firms use Dollar currency in financial report & $(131)$ \\
Less: Firms that financial report no completed & $(51)$ \\
Less: Firms that have been delisted & $(15)$ \\
\hline Total selection of Firms & 175 \\
\hline
\end{tabular}

To test the hypothesis, the researchers estimate the following multivariate regression model:

$$
\text { Mscore }_{i t}=\propto+\beta T A X+\gamma_{1} \operatorname{SIZE}_{i t}+\gamma_{2} L E V_{i t}+\gamma_{3} R O A_{i t}
$$

The dependent variable, M Score, is calculated using the Beneish M-Score model, which captures the manipulation of financial reports. Based on Beneish (1999), the researchers calculate the score using 8 index, such as: Days Sales in Receivables Index (DSRI), Gross Margin Index (GMI), Asset Quality Index (AQI), Sales Growth Index (SGI), Depreciation Index (DEPI), Sales and General Administration Expenses Index (SGAI), Leverage Index (LVGI), and Total Accruals to Total Assets (TATA). Then the results of each index will be included in a model (Beneish, 1999), as follows: MScore $=-4,840+0,920 \mathrm{DSRI}+0,528 \mathrm{GMI}+0,0404 \mathrm{AQI}+0,892 \mathrm{SGI}+0,115 \mathrm{DEPI}-0,172 \mathrm{SGAI}+$ 4,679TATA - 0,327LVGI. Companies with higher M-scores have more possibilities to commit financial report manipulations.

The test variable, TAX, capture firm participation in the tax amnesty program. It will be coded 1 if the firm participated in the tax forgiveness program in 2016-2017, and 0 otherwise. As discussed earlier, the investigation period is on the year before firm participation in tax amnesty with the 
consideration of firms that participated in the tax amnesty are also aggressive in their tax avoidance strategies. As such, the dummy TAX variable will be used consistently throughout the investigation period. The investigation period is the years before tax amnesty; in this case, the researchers use the most recent years; 2012 to 2015. Consistent with prior studies (e.g., Frank, Lynch, \& Rego, 2009; Lennox, Lisowsky, \& Pittmen, 2013), the researchers also control for firm size (SIZE- log natural of total assets, capture in period before tax amnesty), leverage (LEV-the ratio of the firm's long-term debt to total assets, captures in period before tax amnesty), and profitability (ROA- the ratio of net income to total assets, captures in period before tax amnesty).

\section{RESULTS AND DISCUSSIONS}

Table 2 shows the descriptive statistics for 175 sample companies during the sample period.

Table 2 Descriptive Statistics

\begin{tabular}{ccccccccc}
\hline & N & Mean & SD & Min & Q1 & Median & Q3 & Max \\
\hline M SCORE & 796 & $-2,50$ & 1,22 & $-10,46$ & $-2,96$ & $-2,64$ & $-2,20$ & 30,46 \\
TAX & 796 & 0,40 & 0,49 & 0,00 & 0,00 & 0,00 & 1,00 & 1,00 \\
SIZE & 796 & 14,58 & 1,66 & 9,93 & 13,26 & 14,67 & 15,87 & 19,38 \\
LEV & 796 & 0,19 & 0,23 & 0,00 & 0,05 & 0,13 & 0,24 & 2,52 \\
ROA & 796 & 0,07 & 0,09 & $-0,48$ & 0,02 & 0,05 & 0,10 & 2,78 \\
\hline
\end{tabular}

Notes: $M$ SCORE = defined as financial reporting manipulation using Beneish M score model. TAX = defined as tax aggressiveness, code 1 if the company participate in tax amnesty program and 0 if not participate. SIZE $=\log$ natural of total assets, $\mathrm{LEV}=$ the ratio of the firm's long-term debt to total assets, ROA is measured as profitability by divided net income with total asset.

It can be seen from Table 2 that the average number M SCORE is $-2,50$ with standard deviation amounting to 1,22 and median $-2,64$. The tax amnesty measure (TAX) has mean value 0,40 or $40 \%$ the observation in this research participated in tax amnesty program. Firm size (SIZE) has mean value 14,58, while its median value is 14,67 . The average Leverage (LEV) is 0,19 and the median value is 0,13 . The mean Profitability (ROA) is 0,07 or $7 \%$, while the median value is 0,05 . Table 3 shows the correlation matrix of variables used in this research.

Table 3 Correlation Matrix

\begin{tabular}{|c|c|c|c|c|c|}
\hline & M SCORE & TAX & SIZE & LEV & ROA \\
\hline M SCORE & 1,000 & & & & \\
\hline$T A X$ & $-0,051$ & 1,000 & & & \\
\hline SIZE & 0,040 & 0,068 & 1,000 & & \\
\hline$L E V$ & 0,055 & 0,083 & 0,015 & 1,000 & \\
\hline$R O A$ & $-0,062$ & $-0,101$ & 0,136 & $-0,129$ & 1,000 \\
\hline
\end{tabular}

Notes: $M$ SCORE = defined as financial reporting manipulation using Beneish $\mathrm{M}$ score model. TAX $=$ defined as tax aggressiveness, code 1 if the company participate in tax amnesty program and 0 if not participate. SIZE $=\log$ natural of total assets, $\mathrm{LEV}=$ the ratio of the firm's long-term debt to total assets, ROA is measured as profitability by divided net income with total asset.

Table 4 reports the results from the estimation of the empirical model. It presents the results from a model that uses firms' participation in tax amnesty programs for the test variables and financial report manipulation as the dependent variable. Column M-Score presents the regression results using 
firms participate in tax amnesty programs as the test variable. It shows that the coefficient on $T A X$ is negative $(-0,174)$ and significant at the 10 percent level ( $t$-statistic $=0,052)$. To complement the results, sensitivity analysis is also performed. The researchers use the difference of actual value in M-Score with the M-Score's threshold value for the firm's manipulation $(-2,22)$ as the dependent variable. The results (unreported) are qualitatively similar. The results presented in Table 4 show that the companies participating in tax amnesty that can be considered aggressive towards taxation, have a negative significant relation with the manipulation of financial statements. As such, the alternative hypothesis (Ha) is accepted. It can also be conceived that the companies participating in the tax amnesty are not manipulators of financial statement. The result, therefore, supports the previous researches, which finds that aggressive tax activities are negatively related to the aggressive financial statement; for example, Onuma (2013).

Table 4 Linear Regressions of Firms Participate in Tax Amnesty Program on Financial Report Manipulation and Control Variables

\begin{tabular}{|c|c|c|c|}
\hline Variable & Sign & M-score & Standard Error \\
\hline \multirow[t]{2}{*}{ TAX } & - & $-0,174$ & 0,089 \\
\hline & & $0,052 *$ & \\
\hline \multirow[t]{2}{*}{ SIZE } & + & 0,028 & 0,028 \\
\hline & & 0,314 & \\
\hline \multirow[t]{2}{*}{ LEV } & + & 0,072 & 0,319 \\
\hline & & 0,822 & \\
\hline \multirow[t]{2}{*}{ ROA } & + & 1,053 & 0,551 \\
\hline & & $0,056^{*}$ & \\
\hline \multirow[t]{2}{*}{ Cons } & $?$ & $-2,392$ & 0,486 \\
\hline & & 0,00 & \\
\hline Year and industry fixed-effects & & Yes & \\
\hline Adjusted $R^{2}$ & & 0,052 & \\
\hline Prob $>F$ & & 0,0091 & \\
\hline F-statistics & & 2,08 & \\
\hline Observation size & & 796 & \\
\hline \multicolumn{4}{|l|}{ Notes: } \\
\hline \multicolumn{4}{|c|}{$\begin{array}{l}\text { This table presents regression results of Financial report manipulation (Beneish } M \text { score) on firms participat } \\
\text { in tax amnesty program }(\text { dummy } 1 \text { and } 0 \text { ) and control variables. All variables are defined in Appendix A. *, } \\
* * \text {, and } * * * \text { indicate statistical significance at the } 10 \%, 5 \% \text {, and } 1 \% \text { levels, respectively. Significance levels } \\
\text { are for one-tailed } t \text {-tests where a predicted direction is provided, two-tailed otherwise. }\end{array}$} \\
\hline
\end{tabular}

This result is different from Frank, Lynch, and Rego (2009), where they find a positive relationship between tax aggressiveness and financial statements. Frank, Lynch, and Rego (2009) have stated that companies can do both actions at the same time due to the increasing number of tax gap that can be utilized by companies and differences in accounting principles with tax regulations. This research's results are also different from Lennox, Lisowsky, and Pittmen (2013), where they find no significant relationship between aggressive tax actions and aggressive financial statements. They argue that government scrutiny may impair the motivation of firms to commits in both aggressive tax activities and financial reports. However, this research's result is consistent with Onuma (2013), who has found that aggressive financial reporting is negatively related to tax aggressiveness. Onuma (2013) has argued that the negative relation between aggressive financial reporting and tax activities cannot be done because if companies decide to do so, they need to report low profits, which can be a bad signal for the investors.

Specific for the control variables, the researchers only find a significant result for profitability as measured by ROA. It shows that ROA is positively $(1,053)$ and significant at $5 \%$ related to M-Score. It indicates that profitability has a positive significant effect on aggressive financial statement actions. 
The result is similar to Frank, Lynch, and Rego (2009); Kamila (2014) that find that profitability has a significant effect on financial report manipulation. This shows that more profitable firms tend to manipulate their financial statements. This might be related to the condition that more profitable firms face greater public expectations regarding their performance.

To support our baseline result, the researchers further examine the relation of participation in tax amnesty with aggressive tax activities. In doing so, the researchers test the relation between participation in tax amnesty with three proxies to measure the level of tax aggressiveness: Effective Tax Rate (ETR), Cash Tax Rate (CTR), and Book Tax Difference (BTD). The test is conducted by comparing the means of ETR, CTR, and BTD for firms participated in tax amnesty and not participated. Table 5 shows the test using ETR.

Table 5 T-test (ETR - Tax)

\begin{tabular}{|c|c|c|c|c|}
\hline Group & Obs & Mean & Std Err & SD \\
\hline 0 & 480 & 0,218 & 0,025 & 0,549 \\
\hline 1 & 316 & 0,225 & 0,028 & 0,510 \\
\hline Diff & & $-0,007$ & 0,037 & \\
\hline \multicolumn{3}{|c|}{$\begin{array}{c}\text { Diff }=\text { mean }(0)-\text { mean }(1) \\
\text { Ho }: \text { diff }=0\end{array}$} & \multicolumn{2}{|c|}{$\begin{array}{c}\mathrm{T}=-0,1639 \\
\text { Degrees of freedom }=794\end{array}$} \\
\hline \multicolumn{2}{|c|}{$H a ;$ diff $<0$} & $\begin{array}{c}\text { Ha: diff! }=0 \\
\operatorname{Pr}([\mathrm{T}])>[\mathrm{t}]=0,8698\end{array}$ & Ha: diff! > 0 & $\operatorname{Pr}(\mathrm{T}>\mathrm{t}]=0,5651$ \\
\hline
\end{tabular}

Table 5 shows that there is no significant difference in ETR between firms participating in tax amnesty and their counterparts. Table 6 shows the test using CTR. It shows that the mean of CTR for tax amnesty participating firms is significantly different at $10 \%$ from their counterparts. It shows that the CTR for participating firms is higher compared to non-participating firms. It indicates that participating firms are less likely to engage in tax aggressive activities.

Table 6 T-test (CTR - Tax)

\begin{tabular}{|c|c|c|c|c|}
\hline Group & Obs & Mean & Std Err & SD \\
\hline 0 & 480 & 0,322 & 0,045 & 0,995 \\
\hline 1 & 316 & 0,466 & 0,076 & 1,366 \\
\hline Diff & & $-0,144$ & 0,083 & \\
\hline \multicolumn{2}{|c|}{$\begin{array}{c}\text { Diff }=\text { mean }(0)-\text { mean }(1) \\
\text { Ho }: \text { diff }=0\end{array}$} & & & $\begin{array}{c}\mathrm{T}=-1,720 \\
\text { Degrees of freedom }=794\end{array}$ \\
\hline \multicolumn{2}{|c|}{$\begin{array}{c}H a ; \text { diff }<0 \\
\operatorname{Pr}(T t)=0.042\end{array}$} & \multicolumn{2}{|c|}{$\begin{array}{c}\text { Ha: diff! }=0 \\
\operatorname{Pr}([\mathrm{T}])>[\mathrm{t}]=0,085\end{array}$} & $\begin{array}{c}\text { Ha: diff! }>0 \\
\operatorname{Pr}(T>t]=0,957\end{array}$ \\
\hline
\end{tabular}

The result using BTD measure is presented in Table 7. It shows that the participating firms have higher BTD, significant at 5\%, compared to non-participating firms. Table 7 shows that the BTD for participating firms is 0,036 , while it is 0,023 for non-participating firms. This suggests that for BTD, participating firms exhibit greater tax avoidance levels compared to non-participating firms. The results generated by investigating the relation between tax amnesty and tax avoidance show that firms participating in tax amnesty are not aggressive on their tax activities, except for BTD measure. Overall, 
the researchers find an indication that companies participating in the tax amnesty program are not engaged in aggressive tax activities. Furthermore, the researchers also find that participation in the tax amnesty program is related to lower financial statements manipulation.

TABLE 7: T-test (BTD - Tax)

\begin{tabular}{|c|c|c|c|c|}
\hline Group & Obs & Mean & Std Err & SD \\
\hline 0 & 480 & 0,023 & 0,003 & 0,077 \\
\hline 1 & 316 & 0,036 & 0,004 & 0,077 \\
\hline Diff & & $-0,013$ & 0,005 & \\
\hline \multicolumn{2}{|c|}{$\begin{array}{c}\text { Diff }=\text { mean }(0)-\text { mean }(1) \\
\text { Ho }: \text { diff }=0\end{array}$} & & & $\begin{array}{c}\mathrm{T}=-2,325 \\
\text { Degrees of freedom }=794\end{array}$ \\
\hline \multicolumn{2}{|c|}{$\begin{array}{c}H a ; \text { diff }<0 \\
\operatorname{Pr}(T, t)=0,0102\end{array}$} & \multicolumn{2}{|c|}{$\begin{array}{c}\text { Ha: diff! }=0 \\
\operatorname{Pr}([T])>[t]=0,0203\end{array}$} & $\begin{array}{c}\text { Ha: diff! }>0 \\
\operatorname{Pr}(T>t]=0,9898\end{array}$ \\
\hline
\end{tabular}

\section{CONCLUSIONS}

In this research, the researchers investigate the association between participation in the tax amnesty program and financial report manipulation. It finds that participation in the tax amnesty program is related to lower financial statements manipulation. This, therefore, provides supporting arguments to the previous researches. Further, the additional analysis finds that that firms participating in tax amnesty are not engaging in tax aggressive strategies as reflected by their ETR and BTD levels. The researchers predict that firms participate in tax amnesty program is merely to obtain the benefits from the program such as (based on Law No. 11 of 2016): (a) Elimination of taxes that should be owed (PPh and VAT), elimination administrative sanctions, and criminal sanctions; (b) Elimination from administrative sanctions for tax assessments that have been issued, (c) No tax audit, examination of preliminary evidence, and investigation into taxation crime; (d) Termination of tax audits, examination of preliminary evidence and investigation of criminal acts in taxation.

Besides that, the researchers also examine the relationship between tax amnesty and financial reports aggressiveness using only Beneish M-Score. Future research may fill the gap by examining the issue using other financial manipulation measures. Further, they can also examine the issue in a more specific area, such as manipulation of the financial report in the tax area, for example, using restatement of financial statements in tax account.

\section{REFERENCES}

Beneish, M. D. (1999). The detection of earnings manipulation. Financial Analysts Journal, 55(5), 2436.

Buckwalter, N. D., Sharp, N. Y., Wilde, J. H., Wood, D. A. (2014). Are state tax amnesty programs associated with financial reporting irregularities? Public Finance Review, 42(6), 774-799. https://doi.org/10.1177/1091142113499397. 
Dalby, D., \& Wilson-Chapman, A. (2019). Panama papers helps recover more than $\$ 1,2$ billion around the world. Retrieved from https://www.icij.org/investigations/panama-papers/panama-papershelps-recover-more-than-1-2-billion-around-the-world/.

Frank, M. M., Lynch, L. J., \& Rego, S. O. (2009). Tax reporting aggressiveness and its relation to aggressive financial reporting. The Accounting Review, 84(2), 467- 496.

Kamila, P. A. (2014). Analisis hubungan agresivitas pelaporan keuangan dan agresivitas pajak. Finance and Banking Journal, 16(2), 228-245.

Ko, J. K., Choi, E. H., \& Kim, W. Y. (2012). The relation between aggressive financial reporting and aggressive tax reporting: Korean evidence. Korean Accounting Journal, 21(3), 95-130.

Lennox, C., Lisowsky, P., \& Pittmen, J. (2013). Tax aggressiveness and accounting fraud. Journal of Accounting Research, 51(4), 739-778.

Mukarromah, A. (2016). Tax amnesty sebagai awal reformasi pajak. Inside Tax Magazine, 37, 1-69.

Mustami, A. A., \& Caturini, R. (2017). Ada 956.000 WP yang ikut tax amnesty. Retrieved on November $11^{\text {th }} 2018$ from http://www. nasional.kontan.co.id.

Muttaqin, Z., (2013). Tax Amnesty di Indonesia. Bandung: Refika Aditama

Onuma, H., (2013). Tax Reporting Aggressiveness, Financial Reporting Aggressiveness, and Multinational Corporate Development - Evidence from Japan. SSRN Electronic Journal, 1-31. doi: $10.2139 /$ ssrn.2231803.

Republik Indonesia. (2016). Undang-Undang Republik Indonesia Nomor 11 Tahun 2016 tentang Pengampunan Pajak (Lembaran Negara Republik Indonesia Tahun 2016 Nomor 131, Tambahan Lembaran Negara Republik Indonesia Nomor 5899). Jakarta: Sekretariat Negara.

Setyo, A. (2016). Google nunggak pajak lebih dari Rp 5 triliun di Indonesia. Retrieved on November $11^{\text {th }}, 2018$ from http://www.liputan6.com. 